DOI: https://doi.org/10.24127/ajpm.v10i2.3345

\title{
EFEKTIVITAS VIDEO PEMBELAJARAN MATEMATIKA UNTUK MENDUKUNG KEMAMPUAN LITERASI NUMERASI DAN DIGITAL SISWA
}

\author{
Sri Winarni ${ }^{1 *}$, Ade Kumalasari ${ }^{2}$, Marlina ${ }^{3}$, Rohati $^{4}$ \\ ${ }^{1 *, 2,3,4}$ Pendidikan Matematika, Universitas Jambi, Kota Jambi, Indonesia \\ *Corresponding author \\ E-mail: $\quad$ sri.winarni@unja.ac.id ${ }^{* *}$ \\ ade.kumalasari@unja.ac.id $^{2)}$ \\ marlina@unja.ac.id ${ }^{3}$ \\ $\underline{\text { rohati.fkip@unja.ac.id }}^{4)}$
}

Received 03 December 2020; Received in revised form 14 June 2021; Accepted 29 June 2021

\begin{abstract}
Abstrak
Penggunaan media pembelajaran dapat menumbuhkan pembelajaran yang lebih efektif. Ada banyak pilihan media pembelajaran yang dapat digunakan, salah satunya adalah media berupa video pembelajaran. Selain dapat memudahkan siswa memahami konsep dari materi yang dipelajari, video pembelajaran diharapkan dapat mendukung kemampuan literasi numerasi dan digital siswa. Penelitian dilakukan guna melihat efektivitas penggunaan video pembelajaran terhadap kemampuan literasi numerasi dan digital siswa. Jenis penelitian ini adalah penelitian kuasi eksperimen. Desain eksperimen yang digunakan adalah post test only control group design dan teknik analisis data penelitian menggunakan uji manova. Adapun instrumen yang digunakan dalam penelitian yaitu lembar observasi keterlaksanaan pembelajaran, lembar tes kemampuan literasi numerasi siswa, dan angket literasi digital siswa. Subjek penelitian adalah siswa kelas VIII di SMP Negeri 7 Muaro Jambi. Berdasarkan pengolahan data menggunakan uji multivariate diperoleh bahwa $\mathrm{H}_{0}$ ditolak. Berdasarkan uji lanjut menggunakan uji $T^{2}$ Hotelling diperoleh bahwa $\mathrm{H}_{0}$ ditolak. Dengan demikian dapat disimpulkan bahwa kemampuan literasi numerasi dan literasi digital siswa pada kelas eksperimen lebih baik dari pada kelas kontrol. Hal ini berarti penggunaan video pembelajaran pada pembelajaran di kelas efektif ditinjau dari kemampuan literasi numerasi dan kemampuan literasi digital siswa.
\end{abstract}

Kata kunci: Kemampuan literasi digital; kemampuan literasi numerasi; video pembelajaran matematika.

\begin{abstract}
The use of learning media can foster more effective learning. There are many choices of learning media that can be used, one of which is media in the form of learning videos. Besides making it easier for students to understand the material being studied, learning videos are expected to support students' numeracy and digital literacy skills. The study was conducted to see the effectiveness of learning videos on students' numeracy and digital literacy skills. This type of research is quasi-experimental research. The experimental design used was a post-test only control group design, and the research data analysis technique used the manova test. The instruments used in the study were observation sheets on the implementation of learning, test sheets for students' numeracy literacy skills, and student digital literacy questionnaires. The research subjects were students of class VIII at SMP Negeri 7 Muaro Jambi. Based on data processing using the multivariate test, it was found that $H_{0}$ was rejected. Based on further tests using Hotelling's $T^{2}$ test, it was found that $H_{0}$ was rejected. Thus, it can be concluded that the students' numeracy and digital literacy skills in the experimental class are better than in the control class. It means that learning videos in classroom learning are effective in numeracy literacy and digital literacy abilities.
\end{abstract}

Keywords: Digital literacy skills; mathematics learning videos; numeracy literacy skills. 
DOI: https://doi.org/10.24127/ajpm.v10i2.3345

\section{PENDAHULUAN}

Penggunaan media pembelajaran di era digital sangat dibutuhkan untuk meningkatkan kualitas pembelajaran, hal ini dikarenakan penggunaan media ini dapat menumbuhkan pembelajaran yang lebih efektif. (Rohati, Winarni, \& Hidayat, 2018; Kusumah, 2010) Pemanfaatan media dan teknologi dalam pembelajaran sangat perlu diterapkan di kelas, terutama empat jenis multimedia yang digunakan untuk meningkatkan pembelajaran berupa audio, video, teks, dan visual (Heinich, 1998; Smaldino, Lowther, \& Mims, 2019).

Ada banyak pilihan media pembelajaran yang dapat digunakan, salah satunya adalah media berupa video pembelajaran. Video pembelajaran merupakan video yang dirancang khusus untuk media pembelajaran secara efektif yang berisi materi praktis yang tepat sasaran sehingga siswa dapat belajar dengan mandiri dan dapat menunjang dalam pendalaman materi (Niswa, 2012). Menurut Krisna \& Marga (2018) video dapat digunakan secara efektif untuk menyampaikan materi pelajaran matematika. Selain itu penggunaan video ini juga menimbulkan respon positif dari siswa. Hal ini juga sejalan dengan hasil penelitian Rahayu, Prayitno, Tinggi, \& Ronggolawe (2020) dimana pembelajaran menggunakan video dapat meningkatkan minat dan pemahaman konsep siswa.

Semakin kompleksnya tuntutan capaian pembelajaran yang harus dipenuhi menyebabkan media pembelajaran memiliki peran penting. Penggunaan video sebagai media pembelajaran merupakan salah satu pilihan yang dapat memberi dampak pada pembelajaran. Video pembelajaran merupakan media yang dapat mengemas materi pembelajaran dalam penyajian yang lebih menarik. Selain itu, video pembelajaran dapat menayangkan pesan pembelajaran secara realistik, sehingga persoalan dalam pembelajaran menjadi lebih mudah untuk dipahami siswa. Hal ini juga berdampak pada lebih mudahnya siswa untuk mencapai tujuan pembelajaran dan penguasaan konsep yang diharapkan (Prastowo, 2012; Daryanto, 2013; Sudjana \& Rivai, 1992).

Ilmu pengetahuan yang diperoleh siswa harus bermanfaat dalam kehidupan, oleh karena itu siswa diharapkan mampu membuat keterkaitan antara kejadian dalam kehidupannya dengan ilmu pengetahuan yang diperoleh dalam pembelajaran. Kemampuan ini dikenal dengan kemampuan literasi. Menurut Fathani (2016), literasi matematika adalah kemampuan seseorang yang berperan dalam merumuskan, menerapkan, dan menafsirkan seluruh konsep, prosedur, fakta dan alat matematika baik dari sisi perhitungan, angka maupun keruangan dalam konteks kehidupan sehari-hari secara efisien. Literasi matematis yang dimaksud dalam penelitian ini adalah literasi numerasi dan digital. Literasi numerasi adalah kemampuan seseorang dalam memperoleh, menginterpretasikan, menggunakan, dan mengkomunikasikan berbagai macam aspek matematika (angka dan simbol) untuk memecahkan masalah praktis dalam kehidupan sehari-hari. Sedangkan literasi digital adalah kemampuan seseorang dalam menggunakan media digital untuk menemukan, mengevaluasi, dan membuat informasi. Temuannya ini dapat dimanfaatkan dengan tepat dalam rangka membina komunikasi dan interaksi dalam kehidupan sehari-hari (Kemendikbud, 2017). 
Cakupan literasi numerasi bersifat praktis kontekstual, berkaitan untuk memahami isu-isu dalam komunikasi, profesional dalam pekerja, bersifat rekreasi, dan kultural (Ekowati, Astuti, Utami, Mukhlishina, \& Suwandayani, 2019). Kemampuan literasi numerasi penting untuk dikembangkan karena inti dari pembelajaran matematika adalah untuk menemukan solusi permasalahan kontekstual sehari-hari (Pangesti, 2018).

Literasi digital dipandang sebagai kemampuan menggunakan teknologi dan informasi dari piranti digital secara efektif dan efisien (Riel, Christian, \& Hinson, 2012). Namun lebih lanjut literasi digital dipandang sebagai bentuk cara berpikir yang meliputi kesadaran data, kemampuan analisis data, dan kemampuan bekerja secara mendalam (Eshet, 2002; Soegiono, 2019). Sejalan dengan hal tersebut, Literasi digital diartikan sebagai kemampuan seseorang dalam menggunakan media digital untuk menemukan, mengevaluasi, dan membuat informasi. Dimana temuannya ini dapat dimanfaatkan dengan tepat dalam rangka membina komunikasi dan interaksi dalam kehidupan sehari-hari (Kemendikbud, 2017).

Semakin kompleksnya tuntutan capaian pembelajaran yang harus dipenuhi menyebabkan media pembelajaran memiliki peran penting. Penggunaan media tentunya tidak hanya sekedar untuk menarik perhatian maupun minat siswa, namun juga untuk memenuhi tujuan pembelajaran. Berdasarkan karakteristiknya, video pembelajaran diharapkan mampu memvisualkan masalah-masalah yang diangkat dalam pembelajaran ke dalam kelas pembelajaran. Sehingga konteks nyata yang dibawa dalam pembelajaran benar-benar ditampilkan secara nyata, bukan lagi dibayangkan. Dengan demikian diharapkan penggunaan video pembelajaran dapat membantu meningkatkan kemampuan literasi numerasi dan digital siswa. Untuk mendapatkan data yang valid mengenai penggunaan video tersebut, maka dilakukan penelitian guna melihat efektivitas penggunaan video pembelajaran terhadap kemampuan literasi numerasi dan digital siswa.

\section{METODE PENELITIAN}

Penelitian ini adalah penelitian kuasi eksperimen dengan desain posttest only control group design. Secara umum penelitian ini terdiri atas beberapa tahapan, yaitu pemberian perlakuan, pengumpulan data, interpretasi data, dan penarikan kesimpulan. Pemberian perlakuan dilakukan pada dua kelas sampel yang terdiri dari satu kelas eksperimen dan satu kelas kontrol. Pada kelas eksperimen diberlakukan perlakuan yaitu penggunaan video pembelajaran matematika. Pembelajaran pada kedua kelas sampel dilakukan selama tujuh pertemuan. Untuk memperkecil faktor kovariat, maka pembelajaran dilaksanakan oleh guru yang sama. Pengumpulan data dilakukan melalui pemberian posttest pada pertemuan kedelapan.

Penelitian dilakukan di SMP Negeri 7 Muaro Jambi. Penelitian dilakukan pada semester ganjil 2020/2021. Populasi pada penelitian ini yaitu seluruh siswa kelas 8 SMP N 7 Muaro Jambi yang terdiri dari 8 kelas. Sampel pada penelitian ini adalah dua kelas yang dipilih secara random sampling. Dua kelas sampel tersebut terdiri atas kelas eksperimen yang terdiri dari 19 orang siswa dan kelas kontrol 18 orang siswa. Agar teknik sampling dapat dilakukan, maka terlebih dahulu dicek apakah masingmasing kelas berdistribusi normal dan 
varians tiap kelas homogen. Pada penelitian ini, pengujian normalitas dan homogenitas dalam pemilihan sampel dilakukan dengan bantuan SPSS.

Variabel bebas dalam penelitian ini adalah penggunaan video pembelajaran dalam pembelajaran yang dilaksanakan di kelas (X). Variabel terikat dalam penelitian ini adalah kemampuan literasi numerasi siswa $\left(\mathrm{Y}_{1}\right)$ dan kemampuan literasi digital siswa $\left(\mathrm{Y}_{2}\right)$.

Data yang digunakan dalam penelitian ini merupakan data primer yang diperoleh langsung dari sampel penelitian. Data kemampuan literasi digital siswa diperoleh melalui pengisian angket oleh siswa. Data kemampuan literasi numerasi siswa diperoleh melalui pengerjaa soal tes.

Instrumen yang digunakan pada penelitian ini adalah lembar observasi, instrumen tes kemampuan literasi numerasi, dan instrumen angket kemampuan literasi digital. Lembar observasi keterlaksanaan pembelajaran digunakan untuk mengontrol bahwa pembelajaran yang telah dirancang oleh peneliti terlaksana dengan baik. Sehingga hasil yang diperoleh pada kemampuan literasi numerasi dan digital siswa pada akhir penelitian disebabkan oleh penggunaan video pembelajaran. Observasi dilaksanakan pada setiap pertemuan yaitu sebanyak 7 pertemuan. Tes kemampuan literasi numerasi digunakan untuk mengukur kemampuan literasi numerasi siswa. Tes diberikan di kedua kelas sampel pada akhir penelitian, yaitu pertemuan kedelapan. Soal-soal tes disusun berdasarkan indikator kemamuan literasi numerasi. Angket kemampuan literasi digital digunakan untuk mengukur kemampuan literasi digital siswa. Angket diberikan di kedua kelas sampel pada akhir penelitian. Angket ini disusun berdasarkan indikator kemampuan literasi digital. Karena data pada angket merupakan data ordinal, maka data ini akan dikonversi menjadi data interval.

Teknik analisis data terdiri dari analisis deskriptif dan analisis inferensial. Deskripsi data pada analisis deskriptif mencakup keterlaksanaan pembelajaran berdasarkan data yag diperoleh dari lembar observasi, ketercapaian indikator kemampuan literasi numerasi dan digital siswa berdasarkan tes dan angket. Ketercapaian indikator tersebut dideskripsikan dengan statistik deskriptif meliputi rata-rata, nilai minimum, dan nilai maksimum pada kedua kelas sampel. Sebelum diolah secara kuantitatif, data pada angket yang merupakan data ordinal akan terlebih dahulu dikonversi menjadi data interval. Analisis inferensial terdiri atas uji prasyarat, yaitu uji normalitas dan homogenitas, uji hipotesis penelitian menggunakan uji multivariate, dan uji lanjut menggunakan $T^{2}$ Hotelling test.

\section{HASIL DAN PEMBAHASAN}

Proses pembelajaran dilaksanakan sebanyak 3 kali pertemuan pada masing-masing kelas kontrol dan eksperimen. Selama proses pembelajaran berlangsung, tim melakukan observasi guna memastikan bahwa setting pembelajaran berjalan sesuai rancangan, sehingga dapat meminimalisir adanya faktor lain yang mempengaruhi hasil tes.

Berdasarkan hasil pengerjaan tes literasi numerasi dan pengisian angket literasi digital yang diberikan kepada siswa kelas eksperimen dan kelas kontrol, diperoleh data seperti yang disajikan pada Tabel 1. 
DOI: https://doi.org/10.24127/ajpm.v10i2.3345

Tabel 1 Data tes literasi numerasi dan literasi digital siswa

\begin{tabular}{|c|c|c|c|c|}
\hline \multirow[b]{2}{*}{ Aspek } & \multicolumn{2}{|c|}{ Eksperimen } & \multicolumn{2}{|c|}{ Kontrol } \\
\hline & $\begin{array}{c}\text { Literasi } \\
\text { Numerasi }\end{array}$ & $\begin{array}{c}\text { Literasi } \\
\text { Digital }\end{array}$ & $\begin{array}{c}\text { Literasi } \\
\text { Numerasi }\end{array}$ & $\begin{array}{c}\text { Literasi } \\
\text { Digital }\end{array}$ \\
\hline $\begin{array}{l}\text { Rata- } \\
\text { rata }\end{array}$ & 79,37 & 45,58 & 60,06 & 33,11 \\
\hline Min & 72 & 35 & 56 & 24 \\
\hline Max & 90 & 58 & 67 & 47 \\
\hline $\mathrm{n}$ & \multicolumn{2}{|c|}{19} & \multicolumn{2}{|c|}{18} \\
\hline
\end{tabular}

Berdasarkan Tabel 1, secara deskriptif rata-rata literasi numerasi dan literasi digital siswa kelas eksperimen lebih tinggi dari pada kelas kontrol. Namun untuk mendapatkan simpulan yang dapat digeneralisasi maka perlu dilakukan pengujian secara inferensial.

Uji prasyarat pengujian hipotesis penelitian adalah uji normalitas dan uji homogenitas. Uji normalitas digunakan untuk memperlihatkan bahwa apakah data sampel berasal dari populasi yang berdistribusi normal. Berdasarkan data hasil tes kemampuan literasi numerasi dan pengisian angket literasi digital, diperoleh hasil uji normalitas seperti yang terlihat pada Gambar 1 .

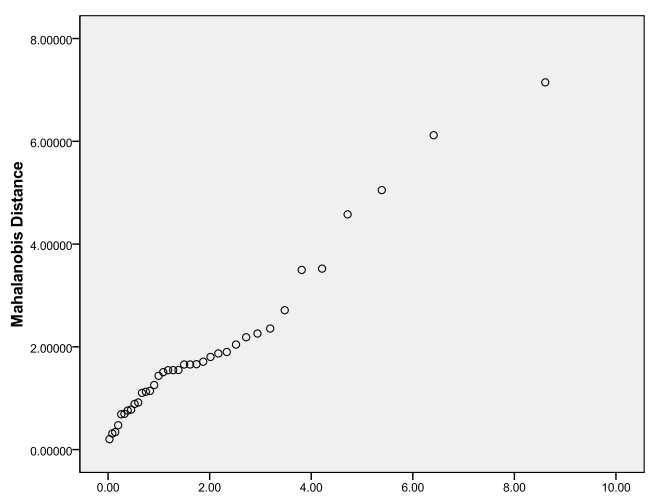

Gambar 1 Grafik q-q plot

Gambar 1 menunjukkan bahwa plot cenderung membentuk garis lurus. Maka dapat dikatakan bahwa data berasal dari populasi berdistribusi normal. Untuk memastikan lebih lanjut dilakukan analisis korelasi bivariate yang dapat dilihat pada Tabel 2 .
Tabel 2 Analisis korelasi bivariate

Correlations

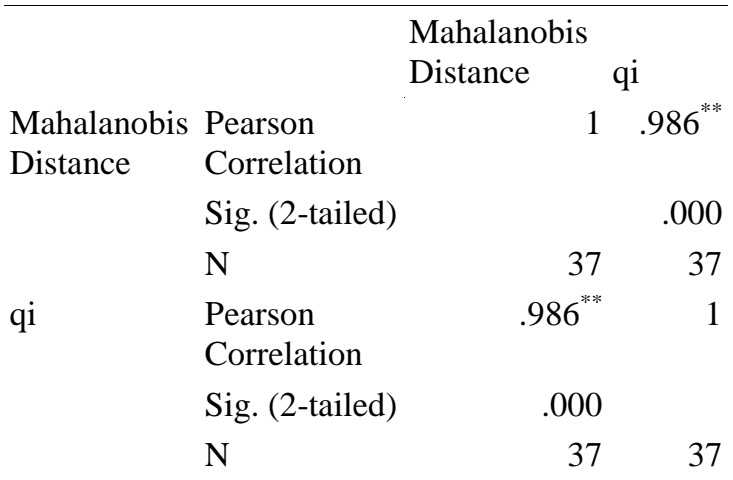

**. Correlation is significant at the 0.01 level (2-tailed).

Berdasarkan Tabel 2 diperoleh bahwa data berasal dari populasi berdistribusi normal. Hal ini ditunjukkan dari nilai korelasi sebesar 0,986 dengan nilai signifikan $0,000<0,05$ (korelasi yang diperoleh signifikan).

Uji homogenitas yang digunakan adalah homogenitas matrik kovarians. Perhitungannya menggunakan uji Box'S M dan hasilnya dapat dilihat pada Tabel 3.

Tabel 3 Uji box's test of covariance matrices

\begin{tabular}{ll}
\hline Box's Test of Equality of Covariance Matrices & ${ }^{\mathrm{a}}$ \\
Box's M & 5.801 \\
F & 1.814 \\
df1 & 3 \\
df2 & 245669.391 \\
Sig. & .142 \\
\hline
\end{tabular}

Tests the null hypothesis that the observed covariance matrices of the dependent variables are equal across groups.

a. Design: Intercept + kelas

Berdasarkan Tabel 3 dapat disimpulkan bahwa asumsi homogenitas terpenuhi. Hal ini ditunjukkan oleh nilai signifikan $0,142>0,05$, dengan demikian dapat disimpulkan bahwa matriks kovarians untuk setiap kelas sampel homogen. 
Uji multivariate dilakukan untuk mengetahui apakah terdapat perbedaan kemampuan literasi numerasi dan literasi digital siswa pada kelas eksperimen yang menggunakan media video pembelajaran dengan kelas kontrol yang tidak menggunakan video pembelajaran. Jika terdapat perbedaan hal ini dapat mengidentifikasi bahwa penggunaan video pembelajaran matematika mempengaruhi kemampuan literasi numerasi dan digital siswa. Adapun hasil penghitungan menggunakan SPSS dapat dilihat pada Tabel 4.

Tabel 4. Uji multivariate.

Multivariate Tests ${ }^{\mathrm{b}}$

\begin{tabular}{lllcccc}
\hline & Effect & Value & \multicolumn{1}{c}{ F } & Hypothesis df & Error df & Sig. \\
\hline \multirow{2}{*}{ Intercept } & Pillai's Trace & .996 & $4508.876^{\mathrm{a}}$ & 2.000 & 34.000 & .000 \\
& Wilks' Lambda & .004 & $4508.876^{\mathrm{a}}$ & 2.000 & 34.000 & .000 \\
& Hotelling's Trace & 265.228 & $4508.876^{\mathrm{a}}$ & 2.000 & 34.000 & .000 \\
& Roy's Largest Root & 265.228 & $4508.876^{\mathrm{a}}$ & 2.000 & 34.000 & .000 \\
\multirow{4}{*}{ kelas } & .844 & $91.794^{\mathrm{a}}$ & 2.000 & 34.000 & .000 \\
& Pillai's Trace & .156 & $91.794^{\mathrm{a}}$ & 2.000 & 34.000 & .000 \\
& Wilks' Lambda & .1500 & 34.000 & .000 \\
& Hotelling's Trace & 5.400 & $91.794^{\mathrm{a}}$ & 2.000 & 34.000 & .000 \\
\hline
\end{tabular}

a. Exact statistic

b. Design: Intercept + kelas

Berdasarkan Tabel 4 diperoleh nilai signifikan pada keempat uji adalah $0,000<0,05$. Dengan demikian $\mathrm{H}_{0}$ ditolak dan dapat disimpulkan bahwa ada perbedaan rata-rata skor kemampuan literasi numerasi dan literasi digital siswa pada kelas eksperimen dan kelas kontrol. Karena $\mathrm{H}_{0}$ ditolak, maka perlu dilakukan uji lanjut.

Karena pada penghitungan multivariat diperoleh hasil $\mathrm{H}_{0}$ ditolak, maka dilakukan uji lanjut. Uji lanjut yang digunakan adalah $T^{2}$ Hotelling Test. Penghitungan uji lanjut menggunakan bantuan Microsoft Office Excel. $\mathrm{H}_{0}$ diterima jika nilai $\mathrm{t}^{2}<\mathrm{c}^{2}$. Adapun nilai $\mathrm{c}^{2}$ dan $\mathrm{t}^{2}$ yang diperoleh dari penghitungan dapat dilihat pada Tabel 5.
Tabel 5 Penghitungan post hoc uji $\mathrm{t}^{2}$ hotelling

\begin{tabular}{|c|c|c|}
\hline & $\begin{array}{c}\text { Kemampuan } \\
\text { Literasi Numerasi }\end{array}$ & $\begin{array}{c}\text { Kemampuan } \\
\text { Literasi Digital }\end{array}$ \\
\hline$t^{2}$ & 12,88 & 7,56 \\
\hline$c^{2}$ & \multicolumn{2}{|c|}{6.75} \\
\hline
\end{tabular}

Berdasarkan Tabel 5 diperoleh bahwa nilai $\mathrm{t}^{2}$ untuk kemampuan literasi numerasi dan literasi digital lebih besar dari $\mathrm{c}^{2}$, dengan demikian $\mathrm{H}_{0}$ ditolak. Karena $\mathrm{H}_{0}$ ditolak, maka dapat disimpulkan bahwa terdapat perbedaan kemampuan literasi numerasi dan literasi digital siswa pada kelas eksperimen dan kontrol. Dikarenakan perbedaan pembelajaran diantara kedua kelas adalah penggunaan video pembelajaran, maka dapat disimpulkan bahwa perbedaan tersebut dikarenakan penggunaan video pembelajaran tersebut. 
Berdasarkan data yang disajikan pada Tabel 1 tampak bahwa rata-rata skor yang diperoleh oleh siswa di kelas eksperimen lebih tinggi dari kelas kontrol. Berdasarkan data pada uji multivariate dan uji lanjut, maka skor kelas eksperimen lebih tinggi secara signifikan dari kelas kontrol. Sehingga berdasarkan uji multivariate diperoleh bahwa penggunaan video pembelajaran matematika untuk mendukung kemampuan literasi numerasi dan literasi digital siswa efektif.

Pada peneitian ini diperoleh bahwa penggunaan media video pembelajaran matematika mampu mengembangkan kemampuan literasi numerasi. Hal ini terlihat bahwa hasil tes literasi numerasi siswa di kelas eksperimen dan kelas kontrol berbeda secara signifikan dengan kondisi secara deskriptif hasil tes di kelas eksperimen lebih tinggi. Hasil yang diperoleh ini sesuai dengan pernyataan Gusmania \& Dari (2018), Muliawanti \& Kusuma (2019) Prastowo (2012), Daryanto (2013), Sudjana \& Rivai (1992) bahwa penggunaan media video pembelajaran ini akan memudahkan siswa dalam mencapai tujuan pembelajaran dan penguasaan konsep yang diharapkan. Kolaborasi antara bentuk media pembelajaran berupa video dan materi ajar yang mendukung kemampuan literasi numerasi mampu meningkatkan/ mengembangkan kemampuan literasi numerasi.

Berdasarkan penelitian yang dilakukan oleh Perdana, Yani, Jumadi, \& Rosana (2019) diperoleh bahwa penyebab kemampuan literasi digital siswa rendah sehingga siswa kesulitan menggunakan perangkat digital dan perangkat lunak. Sedangkan dewasa ini tidak dapat dipungkiri bahwa kondisi pembelajaran secara daring telah memaksa siswa, guru, dan semua yang terlibat dalam proses pembelajaran untuk mampu menggunakan dan memanfaatkan teknologi. Hal ini sesuai dengan hasil yang diperoleh dari penelitian Saman, Ma'rufi, \& Tiro (2019) bahwa solusi yang efektif, efisien, dan praktis dalam menyelesaikan permasalahan pembelajaran sangat erat kaitannya dengan teknologi. Pada peneitian ini diperoleh bahwa penggunaan media video mampu mengembangkan kemampuan literasi digital. Hal ini terlihat bahwa hasil tes literasi digital siswa di kelas eksperimen dan kelas kontrol berbeda secara signifikan dengan kondisi secara deskriptif hasil tes di kelas eksperimen lebih tinggi.

Pemanfaatan

pembelajaran berupa video pembelajaran sangat diperlukan. Xiao, Barnard-brak, Lan, \& Burley (2019) menyatakan bahwa lingkungan yang difasilitasi teknologi berpengaruh terhadap kemampuan literasi dan numerasi. Pemanfaatan teknologi berupa video ini dapat mendukung peningkatan/ pengembangan kemampuan literasi digital siswa. Berdasarkan pengisian angket pada siswa, skor literasi digital siswa lebih tinggi pada kelas eksperimen, hal ini menunjukkan bahwa minat siswa dalam pembelajaran menggunakan video pembelajaran lebih baik dari pada yang tidak menggunakan video pembelajaran. Hal ini sejalan dengan pendapat Krisna \& Marga (2018), Rahayu, Prayitno, Tinggi, \& Ronggolawe (2020), Astriyani \& Fajriani (2020), dan Nini, Aunurrahman, \& Fadillah (2015) bahwa pembelajaran menggunakan video dapat menimbulkan respon positif dan meningkatkan minat siswa dalam pembelajaran. Hal ini terlihat dari antusias siswa dalam mengikuti pembelajaran. 
DOI: https://doi.org/10.24127/ajpm.v10i2.3345

\section{KESIMPULAN DAN SARAN}

Berdasarkan hasil dan pembahasan mengenai penggunaan video pembelajaran matematika dapat ditarik kesimpulan bahwa penggunaan video pembelajaran pada pembelajaran di kelas efektif ditinjau dari kemampuan literasi numerasi dan kemampuan literasi digital siswa.

Adapun saran yang dapat disampaikan adalah pendidik sebaiknya memanfaatkan media pembelajaran secara optimal, khususnya video pembelajaran, tidak sekedar untuk ketercapaian pembelajaran namun juga untuk pengembangan softskill lainnya. Selain itu diperlukan juga penelitian selanjutnya di jenjang yang lebih tinggi, seperti SMA dan perguruan tinggi.

\section{DAFTAR PUSTAKA}

Astriyani, A., \& Fajriani, F. (2020). Pengaruh Penggunaan Media Audio Visual Youtube Materi Pythagoras terhadap Keaktifan Belajar Matematika SIswa. Fibonacci : Jurnal Pendidikan Matematika dan Matematika, 6(1), 87-90.

doi:https://doi.org/10.24853/fbc.6.1 $.87-90$

Daryanto. (2013). Menyusun Modul Bahan Ajar untuk Persiapan Guru dalam Mengajar. Yogyakarta: Gavamedia.

Ekowati, D. W., Astuti, Y. P., Utami, I. W., Mukhlishina, I., \& Suwandayani, B. I. (2019). Literasi Numerasi di SD Muhammadiyah. ELSE (Elementary School Education Journal: Jurnal Pendidikan dan Pengajaran Sekolah Dasar, 3(1), 93. doi:https://doi.org/10.30651/else.v3 i1.2541

Eshet, Y. (2002). Digital Literacy: A New Terminology Framework and
It Application to the Design of Meaningful Technology-based Learning Enviroments. World Conference on Educational Multimedia, (pp. 493-498). Retrieved from http://www.editlib.org.ezproxy.csu. edu.au/index.cfm?fuseaction=Read er.ViewFullText\&paper_id=10316.

Fathani, A. H. (2016). Pengembangan Literasi Matematika Sekolah dalam Perspektif Multiple Intelligences. Edu Sains: Jurnal Pendidikan Sains dan Matematika, 4(2), 136-150. doi:https://doi.org/10.23971/eds.v4i 2.524

Gusmania, Y., \& Dari, T. W. (2018). Efektivitas Penggunaan Media Pembelajaran Berbasis Video terhadap Pemahaman Konsep Matematis Siswa. PYTHAGORAS: Journal of tehe Mathematics Education Study Program, 7(1), 6167.

doi:https://doi.org/10.33373/pythag oras.v7i1.1196

Heinich. (1998). Instructional Media and Technologies for Learning 6th. USA Prentice Hall: Upper Saddle River, NJ.

Kemendikbud. (2017). Panduan Gerakan Literasi Nasional. Jakarta: TIM GLN Kemendikbud.

Krisna, F. P., \& Marga, M. H. (2018). Pemanfaatan Video untuk Pembelajaran Matematika Berbasis Masalah Kontekstual pada Topik Aljabar. Prosiding Seminar Nasional Etnomatnesia (pp. 400405). Yogyakarta: Universitas Sarjanawiyata Tamansiswa. Retrieved from https://jurnal.ustjogja.ac.id/index.ph p/etnomatnesia/article/view/2354

Kusumah, Y. S. (2010). Studi tentang Penerapan Model Pembelajaran Matematika Berbasis Komputer 
Tipe Interaksi Tutorial dalam Peningkatan Kemampuan Berpikir Kritis dan Kreatif Siswa. Seminar Nasional Pendidikan Matematika. Bandung: FMIPA UPI.

Muliawanti, S., \& Kusuma, A. B. (2019). Literasi Digital Matematika Di Era Revolusi Industri 4.0. Prosiding Sendika. 5, pp. 317-324. Purworejo: Departement of Mathematics Education Universitas Muhammadiyah Purworejo. Retrieved from http://eproceedings.umpwr.ac.id/in dex.php/sendika/article/view/728\#: $\sim:$ text=LITERASI\%20DIGITAL\% 20MATEMATIKA\%20DI\%20ER A\%20REVOLUSI\%20INDUSTRI $\% 204.0,-$

Sari\%20Muliawanti\%2C\%20Angg un\&text=Revolusi\%20Industri\%20 $4.0 \% 20$ merupakan\%20hal\%20yang $\% 20$ sering\%20dibicarakan

Nini, Y., Aunurrahman, \& Fadillah. (2015). Pemanfaatan Multimedia Interaktif pada Model Problem Based Learning dalam Pembelajaran Matematika di Kelas VIII. Jurnal Pendidikan dan Pembelajaran Khatulistiwa, 4(11). Retrieved from https://jurnal.untan.ac.id/index.php/ jpdpb/article/view/12314

Niswa, A. (2012). Pengembangan Bahan Ajar Mendengarkan Berbasis Video. Jurnal Bahasa dan Sastra Indonesia, 1(1). Retrieved from

https://media.neliti.com/media/publ ications/241362-pengembanganbahan-ajar-mendengarkan-ber0afe1078.pdf

Pangesti, F. T. (2018). Menumbuhkembangkan Literasi Numerasi pada Pembelajaran Matematika dengan Soal HOTS. Indonesian Digital Journal of
Mathematics and Education, 5(9), 566-575.

Perdana, R., Yani, R., Jumadi, J., \& Rosana, D. (2019). Assessing Students' Digital Literacy Skill in Senior High School Yogyakarta. JPI (Jurnal Pendidikan Indonesia), $8(2)$, 169. doi:http://dx.doi.org/10.23887/jpiundiksha.v8i2.17168

Prastowo, A. (2012). Panduan Kreatif Membuat Bahan Ajar Inovatif. Yogyakarta: Diva Press.

Rahayu, R. D., Prayitno, E., Tinggi, S., \& Ronggolawe, T. (2020). Minat dan Pemahaman Konsep Siswa dalam Pembelajaran Berbasis Problem Based Learning Berbantuan Media Video. JIPVA (Jurnal Pendidikan IPA Veteran), 4(1), 69-80. doi:https://doi.org/10.31331/jipva.v $4 \mathrm{i} 1.1064$

Riel, J., Christian, S., \& Hinson, B. (2012). Charting Digital Literacy: A Framework for Information Technology and Digital Skills Education in the Comunity Collage. Innovations 2012. Philadelphia: League for Innovation in the Community Collage.

Rohati, Winarni, S., \& Hidayat, R. (2018). Pengembangan Media Pembelajaran Komik Matematika Berbasis Problem Based Learning dengan Manga Studio V05 dan Geogebra. Edumatica : Jurnal Pendidikan Matematika, 8(2), 8191.

doi:https://doi.org/10.22437/edumat ica.v8i2.5486

Saman, S., Ma'rufi, M., \& Tiro, A. (2019). Pengembangan Video Pembelajaran Matematika dalam Meningkatkan Minat dan Prestasi Belajar Siswa pada Materi Persamaan Linier Dua Variabel. 
DOI: https://doi.org/10.24127/ajpm.v10i2.3345

Pedagogy: Jurnal Pendidikan Matematika, 4(1), 1-5. doi:DOI: http://dx.doi.org/10.30605/pedagog y.v4i1.1426

Smaldino, S. E., Lowther, D. L., \& Mims, C. (2019). Instructional Technology and Media for Learning. United States: Pearson.

Soegiono, A. N. (2019, Januari 28). Tiga Aspek Literasi Digital: Mengapa Ponsel Membuat Anda Sulit Fokus. Retrieved Februari 20, 2020, from The Conversation: http://theconversation.com/tigaaspek-literasi-digital-mengapaponsel-membuat-anda-sulit-fokus103062

Sudjana, N., \& Rivai, A. (1992). Media Pembelajaran. Bandung: CV Sinar Baru Bandung.

Xiao, F., Barnard-brak, L., Lan, W., \& Burley, H. (2019). Examining Problem-solving Skills in Technology-rich Environments as Related to Numeracy and Literacy. International Journal of Lifelong Education, 327-338. doi:https://doi.org/10.1080/026013 70.2019.1598507 